\title{
The Usage of Digital Ecosystem in Building Material Industry
}

\author{
Murtazaev S-A.Y. \\ Kh. Ibragimov Complex Institute of the \\ Russian Academy of Sciences \\ Academy of Science of the Chechen Republic \\ Grozny State Petroleum Technical University \\ named M.D. Millionschikov \\ Grozny, Russia \\ s.murtazaev@mail.ru \\ Taymaskhanov Kh.E. \\ Department of materials science and engineering \\ Kh. Ibragimov Complex Institute of the Russian Academy \\ of Sciences \\ Technical sciences department \\ Academy of science of the Chechen Republic \\ Grozny State Petroleum Technical University \\ named M.D. Millionschikov \\ Grozny, Russia \\ s.murtazaev@mail.ru
}

\author{
Kuladzhi T.V. \\ Higher School of Economics, Management and Law \\ Northern (Arctic) Federal University \\ named M.V. Lomonosov \\ Arkhangelsk, Russia \\ kuladzhit@list.ru
}

Salgiriev R.R.

Department of materials science and engineering Kh. Ibragimov Complex Institute of the Russian Academy of Sciences

Institute of economy and law

Grozny State Petroleum Technical University named M.D. Millionschikov

Grozny, Russia

rsalgiriev@mail.ru

\author{
Aliev S.A. \\ Building faculty \\ Grozny State Petroleum Technical University \\ named M.D. Millionschikov \\ Grozny, Russia \\ asa-fenix@mail.ru
}

\begin{abstract}
The development of modern industries with innovative technologies for the construction materials industry, including products and structures for construction purposes made of composites and construction plastics, nano-structured and other construction materials is outlined in the "Strategy for the development of construction materials industry for the period up to 2020 and to 2030 in the future." At the stage of the development of technological innovations under the conditions of digitalization of production, an improved method is currently in demand. The calculations of the expenses of production, makes it possible to digitize and determine, as well as to plan and predict the effectiveness of production. In this regard in order to determine the expenses indicators of the products of building materials industry, products and structures under the conditions of digitalization of production, the use of the matrix formula of Professor M.D. Kargopolov is recommended.
\end{abstract}

Keywords-innovation, composite and nano-structured building materials, the matrix formula of Professor M.D. Kargopolov, digitalization of production, digital ecosystem

\section{INTRODUCTION}

In the "Main areas of activity of the Government of the Russian Federation for the Period up to 2024" [1], a key document on strategic planning at the present stage, national goals, main objectives and priorities of the Government of the Russian Federation are identified. The provision of the implementation of the Presidential Decree and strategic objectives of the development of the Russian Federation for the period up to 2024 [2] on the breakthrough scientific, technological and socio-economic development of the country presupposes an increase in the number of organizations performing technological innovation, up to 50 percent of their total and insurance of the rapid introduction of digital technologies in the economy and social sphere, etc.

Among the key actions in this area, a number of national goals are indicated, including: the promotion of the development of distance learning programs in the fields of technological innovation and management; the use of mechanisms for state support of engineering activities; the promotion of the development of digital services to support innovation; the implementation of innovative development programs and digital transformation strategies of leading companies with state participation, etc.

The achievement of the above-mentioned targets is ensured by the implementation of programs [1]: "National Technology 
Initiative of national projects "Science", "Digital Economy of the Russian Federation", "Small and medium-sized businesses and support for individual entrepreneurial initiatives", "Increase in labor productivity and employment support", "Education", State programs of the Russian Federation: "Economic development and innovative economy", "Development of science and technologies" 2013-2020, "Development of education", "Information Society (2011 2020 years)", "Development of industry and increase of its competitiveness", "Energy efficiency and energy development".

Thus, according to paragraph 11 [1], by 2024, the Government of the Russian Federation, together with the state authorities of the constituent entities of the Russian Federation, when implementing the national program "Digital Economy of the Russian Federation", must to carry out "the transformation of priority sectors of economy and social sphere, including health care, education, industry agriculture, construction, urban economy, transport and energy infrastructure, financial services" introducing digital technologies and platform solutions. The functions of the federal executive body responsible for the implementation of the directions "Formation of Research Competences and Technological Grounds", "Information Infrastructure" and "Information Security", according to a resolution of the Government of the Russian Federation [3], are performed by the Ministry of Digital Development, Communications and Mass Communications of the Russian Federation [4].

According to the "Main Directions for the Implementation of the Digital Agenda of the Eurasian Economic Union until 2025" [5], the world economy is at the stage of "profound structural transformations and development of digital economy, when digital transformation of everyday life, business environment and public administration" occurs, and actors in such ecosystems are different physical, legal, virtual and other entities that form an open, sustainable system of relationships and relationships in digital form, supporting the following principles: legal partnership, development of integration and cooperation etc. These principles are aimed at the implementation of national digital agendas outlined in the strategic documents on the digital transformation of the European and Asian member states [5].

According to the "The plan of measures in the direction of "The formation of research competencies and technological reserves" of the program "Digital economy of the Russian Federation" [6], a "Software platform for improving production efficiency" is being developed, aimed at creating software [7] for building models of "existing or future production, identifying constraints and building an ideal model, taking into account the parameters set for achieving the goals (increased profits, reduced costs, increased efficiency, etc.)" [6].

This software is indented to solve problems in the production of building materials, products and structures. In the industry of building materials (products) and building structures, the functions of developing state policy and law regulation are carried out by the Ministry of Industry and Trade of the Russian Federation [8]; previously, these functions were assigned to the Ministry of Construction, Housing and Utilities of the Russian Federation [9].

Nowadays in the industry of building materials there are two strategies: "The strategy of development of the industry of building materials for the period up to 2020 and the future perspective until 2030" (Strategy - 2030) [10] and "The strategy of development of the industry of building materials and industrial housing construction to the period up to 2020 " (Strategy 2020) [11].

Thus, in Strategy - 2030 [10] it is noted that the development of industry enterprises depends on the existing and prospective competitive advantages and economic specialization of the subjects of the Russian Federation, as well as the goals, objectives and priorities of the spatial development strategy of the Russian Federation with the creation of a "state information system of the industry, on the basis of which it is planned to develop an interactive map of building materials industry of the Russian Federation", which, in the current mode, will allow to observe enterprises location in a region, which will contribute to more rapid identification and assessment of problems in the industry. Moreover it will prioritize the deployment of new industry enterprises in the Russian Federation, as well as enhance the ability of intra- and interindustry technology, investment and marketing cooperation [10].

Currently, the coordinating body for ensuring the interaction between federal executive authorities and executive authorities of constituent entities of the Russian Federation "on the development of ecosystems of digital economy and increase of the use of information technologies and communications in order to form an information society and electronic government in the Russian Federation" is "Government committee on digital development, use of information technology, improvement of the quality of life and the conditions of enterprise activities" [12].

In order to determine the expenses indicators of products of digitalized production, a computational model with the matrix formula of Professor M.D. Kargopolov is recommended. With the help of this formula it is possible to perform all the calculations simultaneously, which is relevant and in demand when analyzing and forecasting production expenses indicators for both design solutions and production problems, taking into account various market conditions of production [13-18].

\section{Methods AND MATERials}

Currently, digital economy is seen as part of economy where "the processes of production, distribution, exchange and consumption have gone through digital transformations using information and communication technologies", while the member states of the Eurasian Economic Union "independently develop, form and implement national policies in the areas of digitalization of economy, communication and informatization, ensuring the stable functioning and security of a unified information space and infrastructure communication" [5].

In the "Main areas of activity of the Government of the Russian Federation for the period up to2024" [1], it was noted that in 2016 the number of organizations of technological innovations in the country was 7.3 percent, which was not enough to accelerate the technological development of 
economy, and in analyzing the state and mechanisms for achieving national development goals, with reference to the report "Global Information Technologies" [1], it was shown that the Russian Federation "occupies the 41st place in readiness for the digital economy (Network Readiness Index (NRI)) and was found in the middle of the second group of countries (catching up) on the index of digital economy and society (I-DESI)".

Today in Russia, the mechanisms for "managing the changes in the regulation of digital economy" are in demand, including adapting regulatory frameworks to the challenges of digital development, taking into account the acceleration of the introduction of digital technologies in economy and social sphere, in order "to conduct research and development in digital economy, which requires the creation of a research and development management system ensuring coordination of the efforts of the state, companies, educational institutions of higher education and research organizations" [1].

Therefore, in paragraph 2 "Digitalization and Scientific and Technological Development" of Section 2 [1] scientific and technological development and innovation activities were named as factors for increasing and maintaining the competitiveness of the Russian economy, taking into account the implementation of a set of federal projects on "Digital Economy of the Russian Federation", including the creation of "digital platforms for implementing research and development in the areas of "cross-cutting" digital technologies, etc.

In paragraph 3.4 "The development of basic industries" the tasks are set in order to improve the "quality of management of investment projects and capital investments in the creation of individual facilities", the development of the "system infrastructure of logistics and transport and technological systems for delivery," etc. Thus in order to develop the construction industry, it is necessary to "introduce advanced technologies in design and construction, including the transition to the life cycle management system of capital construction object through the information modeling technology", the development of a pricing system in the construction industry, etc. [1].

According to the decree of the Government of the Russian Federation [19], a draft order "On approval of the Spatial Development Strategy of the Russian Federation for the period up to 2025 " is currently being developed, which envisages the creation of 14 macro-regions of Russia: Central, Central Black Earth, North-West, North, South Caucasian, Volga-Kama, Volga-Ural, Ural, West Siberian, South Siberian, Yenisei, Baikal and Far East.

For the classification of these territories, "the largest and large urban agglomerations will be allocated; cities with a population of $100,000-500,000$ people; small and mediumsized cities, rural areas outside the largest and large urban agglomerations; mineral resource centers; geostrategic territories "[19], which will allow further planning and forecasting of the development of economic complexes of macro-regions using the digitalization mechanism of macroregion production, including the activity of the industry of building materials, products and structures.
It is necessary to note that digitalization is the term of the "digital twenty" - Digitalisation, which gave rise to models with digital platforms with global markets in global online network [20].

In our country, the relations associated with the use of information technologies are regulated by the law "On Information, Information Technologies and Information Protection" [21], in which information technologies represent "processes, methods of searching, collecting, storing, processing, providing, disseminating information and ways of implementing such processes and methods," and the information system, respectively, is "the complex of the information contained in the databases and ensuring the processing of information technologies and means".

The sphere of application of information technologies includes state regulation of relations "associated with the search, receipt, transfer, production and distribution of information using information technologies (informatization)" [21].

The goals and objectives of state management of the building materials industry in Strategy - 2030 [10] are developed taking into account the current provisions of the "Projection of the long-term socio-economic development of the Russian Federation for the period up to 2030", "The forecast of scientific and technological development of the Russian Federation up to 2030", as well as the law "On Strategic Planning in the Russian Federation" [22], and in the previously adopted Strategy - 2020 [11], the provisions of the "Concept of long-term socio-economic development of Russia Federation for the period up to 2020 ", the "Energy Strategy of Russia up to 2030", "Transport Strategy of the Russian Federation for the period up to 2030 " and other industrial policies and strategies for socio-economic development of the Russian Federation.

Currently, the "Plan of measures for the implementation of the Strategy for the development of the building materials industry for the period up to 2020" [23] is being implemented, including proposals for the development of the information industry subsystem of the building materials industry in the State Industry Information System (SIIS) and a section on innovative building materials (products) and structures and their production technologies". Thus, in the section "Management of quality and assortment of building materials," the practice of "creating innovative building materials (products) and structures, including using composite materials", as well as technologies for the production of building materials (products) using wastes derived from recycling production and consumption waste of products and raw materials, etc. [23] is analyzed.

The current state of national economy and its development potential are determined by the production of such types of building materials [10], such as: "cement, small wall materials, prefabricated reinforced concrete structures and products, heatinsulating products, roofing and waterproofing materials, sheet glass, asbestos-cement products, ready-made concrete and mortars, gypsum and plaster products, building lime, dry building compounds, expanded clay, natural facing materials, building metal structures and products, sawn timber, wooden 
building structures, chalk and non-calcined dolomite, slate, gravel, sand, clay and kaolin".

The main consumers of these products are [10]: "construction industry, building materials industry, road industry, railway track facilities, housing and utilities services, oil and gas industry", etc.

The draft order of the Ministry of Construction of Russia "On the approval of the classification methodology for building materials, products and structures, and the determination of normative terms of their operation" [24] shows the "requirements for the structure and content of the classification of building materials, products and structures" and prepared "recommendations for determining the regulatory deadlines of their operation" taking into account the service life of industrial buildings and structures and the frequency of major repairs of buildings and structural elements [24].

For the evaluation under the conditions of digitalization of production efficiency it is recommended to use the matrix formula of Professor M.D. Kargopolov [25-27], developed taking into account the works of V.V. Leontiev [28], V.V. Kossov [29] et al. on interindustry balances and technical financial plans of the Soviet period, where material balance models were commonly regarded as a system expressing the requirement of a balance between the amount of production produced by individual economic objects and the total need for it. Such a descriptive (analytical) model of the matrix formula allows simultaneous and accurate calculating of all expenses indicators of products produced in market conditions, and meeting modern requirements taking into account the influence of various territorial factors of production in identifying the economic efficiency of producing innovative products of building materials and structures in digital economy [13-18].

At the present stage, the law "On innovative science and technology centers ..." [30] regulates relations connected with the creation of innovative science and technology centers on the territory of the Russian Federation and ensuring both "their functioning in order to realize the priorities of the scientific and technological development of the Russian Federation" and enhancing the "investment attractiveness of research and development, the commercialization of their results, expanding the access of citizens and legal entities to participate in promising, commercially attractive scientific and technological projects" [30].

The main goal of industrial policy is "the formation of a high-tech, competitive industry that ensures the transition of the state's economy from the export-raw type of development to the innovative type of development" (p. 1.1. [31]).

For the purpose of automating the processes of collecting and processing information, the state information industry system (SIIS) [31] is used, which ensures the implementation of "industrial policy and the exercise of powers of federal executive authorities to stimulate industry, inform about the support provided to subjects of industry activity, and also to improve the efficiency of information exchange on the state of the industry and its development forecast", taking into account the principles of completeness, credibility, general availability and timeliness of information for inclusion in the SIIS, where information is generated on the state of the industry and its development forecast, on industry stakeholders, on the forecast and actual release of the main types of industrial products with their characteristics, taking into account the industry sector, and also on the volume of imports of industrial products to the Russian Federation (by type of products), on measures to stimulate activity in the field of industry, including the fields of industrial park, industrial technology and clusters [31].

Currently, the Ministry of Digital Development, Communications and Mass Communications of the Russian Federation [4] and the Government Commission on the Use of Information Technologies for the improvement of the quality of life and conditions for doing business", is making conclusions on the expert assessment of documents on budget allocations for the use of information and communication technologies in the activities of state bodies [12].

It should be noted that the goals of digital agenda of the "Eurasian Economic Union" [5] are aimed at ensuring "highquality and sustainable economic growth of member states, including the acceleration of the transition of economies to a new technological structure, the formation of new industries and markets, and the development of labor resources", with synchronization of digital transformations and formations of conditions for the development of industries of the future.

The implementation of digital agenda provides the promotion and emergence of digital initiatives and projects in cross-industry processes, representing "inter-industry processes integrating the activities of subjects from various sectors of economy" defining an effective model of interaction and building business processes in a new field", as the regulatory apparatus provides the elaboration of mechanisms and rules of regulation of economic processes in the framework of digital initiatives and projects "based on digital platform services", representing a system using a "digital processes, resources and services and significant number of subjects of digital ecosystem".

The criteria for initiatives elaboration include the conditions for achieving the goals of digital agenda when using innovative business models and mature developments leading to modernization effects that ensure economic growth and support the competitiveness of member states" economies during digital transformations [5].

The development of the industry of building materials, products and structures is aimed at the creation of high-tech, competitive, sustainable and balanced (in terms of supply and demand) innovative building materials industry, which at the present stage provides national and international markets with high-quality, affordable and energy-efficient products, and therefore, it completely depends on the level of investment activity, which reflects both the volume of investments in fixed capital and the demand for them from industrial consumers and population.

Paragraph 1 "The improvement of the system of spatial distribution of enterprises", section IV of the Strategy - 2030 [10] notes that the forecast balance of supply and demand for the medium and long term periods "will be a tool to carry out coordinated federal and regional industrial policies in the field 
of placement and development of the building materials industry, taking into account the economic specialization of the constituent entities of the Russian Federation" [10]. Therefore, indicators of the volume of demand for innovative building materials by constituent entities of the Russian Federation are currently "required and based on a single information database on advanced materials and technologies used in construction". Moreover they are necessary to justify the construction of a new enterprise or modernization (reconstruction) of an existing enterprise and etc. [10].

For investors, it is always essential to determine the expenses indicators of the products produced. For the calculation of production expenses [25, 27] Professor M.D. Kargopolov proposed a matrix formula: $\mathbf{P}=P=\left(E-A^{\mathrm{T}}\right)^{-1} * \mathrm{D}^{\mathrm{T}}$ $* \mathrm{C}$, which allows simultaneous and precise determination of expenses indicators, as well as prices of products.

This formula has the following notations:

$\mathbf{P}=\left\|\mathbf{p}_{j}\right\| ; \quad j=\overline{1, n}-$ the desired column vector of industrial (full) expenses of production per unit of production (works, services);

- $\mathbf{A}=\left\|\mathrm{a}_{\mathrm{i}}\right\|, \quad i=\overline{1, n}, j=\overline{1, n}-$ matrix $n \times n$ rate of consumption of resources of own production;

- $\mathbf{E}-n \times n$ unit matrix, similar in dimension to matrix $\mathbf{A}$;

- $\mathbf{D}=\left\|\mathbf{d}_{\mathrm{i}}\right\|, \mathrm{i} \in \mathrm{LUR}, j=\overline{1, n}$ - primary resource rate matrix $(L$ - variables, $R$ - constant),

- ${ }^{\mathbf{T}}$ - transpose mark for matrices $A$ and $D$;

- $\mathbf{C}=\|\mathbf{c}\|, i \in \mathrm{LUR},-$ column vector primary stock price

This formula is presented in Microsoft Office Excel in the following form: = MMULTIPL (MMULTIPL (MREV (ETRANSP (A)); TRANSP (D));C).

Here, the following generally accepted in world practice notations are used: MMULTIPL - calculating the product of matrices stored in arrays, MREV - defines the inverse matrix (which is stored in the array), and TRANSP - produces a transposed array [35].

According to the matrix formula of Professor M.D. Kargopolov in terms of digitalization with absolute accuracy and simultaneously, you can calculate all the expenses indicators of products produced in organizations, which is essential for organizations of any legal form, including those of clusters [13-19, 36-43].

\section{RESULTS}

The Strategy-2030 [10] reflects the modern goals and objectives of public administration and outlines the solutions in industry, taking into account the needs and the available raw material base, and therefore the Strategy-2030 currently serves as the basis for developing state programs (sub-programs) of the Russian Federation and constituent entities of the Russian Federation, and other documents aimed at the development of the building materials industry, taking into account the needs and the available raw materials base.
In this Strategy-2030 [10] the issues of creating in the Russian Federation modern high-quality, energy-saving and competitive production of building materials, products and structures for both national and international markets are actualized. Therefore, the Strategy - 2030 allows concluding that "the qualitative development of national economy and the improvement of its competitiveness are inextricably linked with the creation of conditions for taking significant positions in global and national markets due to such factors as technological breakthroughs, participation in the global "chains "of added value formation, the development of new materials, the introduction of innovative technologies into production processes (including nanotechnologies), as well as the reduction of costs and productivity growth". Innovation technologies in the industry provide the creation [10]: of products and structures for construction purposes made of composites and engineering plastics, or with their use; nanostructured building materials with improved characteristics due to the use of mechanochemical activation of raw materials; nano-cements and concretes based on them with the use of modified sulfur binder, preventing the occurrence of corrosion of concretes and contributing to a significant increase in the service life of facilities; low-clinker composite binders using: metallurgical slag, ash and slag waste from heating power plants, as well as binders without cement, and other options with the involvement in the production of building materials of industrial waste as a raw material.

According to section III "Goals, objectives, priorities and stages of the Strategy implementation" [10] up to 2030 the industry envisages an increase in the competitiveness of Russian building materials, allowing reducing the share of imported building materials three times in total consumption volume (compared to the level of 2014), and a threefold increase in the share of export products.

The implementation of the state program of the Russian Federation "Economic development and innovative economy" [33] includes increasing innovation activity and creating of a favorable entrepreneurial environment in the country for doing business, with the solution of a number of tasks: the creation of condition for the development of competition and attracting of investment to economy, the provision for economic organizations of the country with "managerial personnel meeting the modern requirements of economy", etc.

Among the expected results there are indicators both on raising the position of the Russian Federation in the World Bank's Doing Business rating to 20th place by 2018, and on improving the "quality of the current system of strategic documents and creating practical mechanisms for their implementation" and etc.

The state program of the Russian Federation "Information Society (2011-2020)" [34] implements the following subprograms: 1. "Information and telecommunication infrastructure of the information society and services provided on its basis", 2. "Information environment", 3. "Security in Information Society ", 4." Information State", which aims to reduce costs in economy as a result of "standardization of processes, interaction environment and the introduction of information and telecommunication technologies", which 
requires the creation of appropriate information and telecommunication infrastructure throughout the country [34]. For example, in 2018, subsidies were provided in the amount of 27.88 million rubles for regional information technology projects for four constituent entities of the Russian Federation in the North Caucasus Federal District: the Republic of Ingushetia, Kabardino-Balkaria, the Karachay-Cherkess Republic, the Republic of North Ossetia - Alania, and in 2016 -2017 the subsidies in the amount of 93.075 million rubles for the implementation of similar projects were provided to: the Republic of Dagestan, the Karachay-Cherkess Republic, the Chechen Republic and the Stavropol Territory (III the directions for the development of priority areas) [34].

Under the conditions of digitalization of production, the issues of efficiency and competitiveness of the manufactured products remain relevant. Therefore, in already published papers [36-43 and others] the algorithms and examples of calculations are given, along with recommendations on the use of the matrix formula of Professor M.D. Kargopolov, developed to perform calculations of expenses of production in cluster in a digitized form according to the following formula:

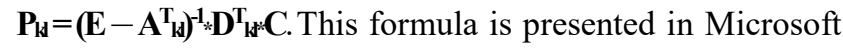
Office Excel in the following form: = MMULTIPL (MMULTIPL (MREV (E- TRANSP (A)); TRANSP (D));C). way:

Analysis matrix: $\mathbf{P}_{\mathbf{k l}}, \mathbf{A}_{\mathbf{k l}}, \mathbf{D}, \mathbf{C}$ is described in the following

- Matrix $\mathbf{P}_{\mathbf{k l}}$ - the calculated matrix, the desired calculated column-vector of the expenses of a unit of production (works, services), where the calculated indicators of the expenses of all intermediate elements and the final estimated expenses of the finished product in a cluster are formed taking into account the tables: $\boldsymbol{A}_{\boldsymbol{k} \boldsymbol{l}}$, D and C and calculated in Microsoft Office Excel.

- Matrix $\boldsymbol{A}_{\kappa \imath}=\left\|\mathrm{a}_{\mathrm{i}, \mathrm{j}}\right\|_{\mathrm{nxn}} i=j=\overline{1, n}$ - a square matrix with coefficients of material expenses in terms of their use: where the row shows the consumption of the $\mathrm{i}$-th resource consumed in the production of a unit of each j-th product (d matrix $\mathbf{A}_{\mathbf{k}}$ in the vertical and horizontal is always an equal number of columns and rows, which indicate the amount of use of own cluster production in a unit of final production, (sign $\mathrm{T}$ TRANSP - provides a transposed array of matrix data $-\mathbf{A}^{\mathbf{T}} \mathbf{k}_{\mathbf{l}}$ );


where $l$ are conditionally variable and $r$ are conditionally constant primary resources consumed in the production of a unit of $\mathrm{j}$-th product. In this matrix it is important to correctly determine the consumption rates of all resources used for the manufacture of innovative products (determined by actual data or taken according to current standards) (T sign - TRANSP provides a transposed matrix data array $-\mathbf{D}^{\mathbf{T}} \mathbf{k}$.)

- Matrix $\boldsymbol{C}=\left|\begin{array}{llll}\mathrm{c}_{1} & \mathrm{c}_{\mathrm{L}} & \mathrm{c}_{\mathrm{r}} & \mathrm{c}_{\mathrm{R}}\end{array}\right|_{\mathrm{L}+\mathrm{R}}$ represents the column-vector of wholesale procurement prices of all primary resources $(l-$ conditionally variable, $r$-conditionally constant) specified in Matrix D in a single monetary system. It should be noted that if in the matrix D resources have value indicators (that is, they are indicated in monetary units), then in matrix $\mathrm{C}$ these resources are denoted as 1 (unit).
- Matrix $\boldsymbol{E}$ - a unit matrix $n \times n$.

\section{CONCLUSION}

1. At the present stage, the issues of digitalization of production, the development of digital technologies are relevant, where the subjects of digital ecosystem are physical, legal and other entities that constitute an open, stable system of relations and relationships in digital form to implement the principles of equal partnership and develop integration and cooperation within national digital agendas identified in the strategic documents of the state, and digital economy is considered as a part of economy, where production processes, distribution, exchange and consumption have undergone digital transformation, using information and communication technologies.

2. Under the conditions of digitalization of production, the algorithms for economic calculations and calculation models for the expenses indicators of products are needed, which can simultaneously and accurately determine all expenses indicators of digitalized production, as well as analyze and predict the possibility of reducing the expenses of production

3. Under the conditions of digitalization of production, the issues of efficiency and competitiveness of the manufactured products remain relevant. Therefore, in already published papers [36-43 and others] the algorithms and examples of calculations are given, along with recommendations on the use of the matrix formula of Professor M.D. Kargopolov, developed to perform calculations of expenses of production in cluster in a digitized form according to the following formula:

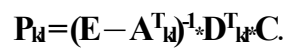

This formula is presented in Microsoft Office Excel in the following form: = MMULTIPL (MMULTIPL (MREV (ETRANSP (A)); TRANSP (D));C)

4. Under the conditions of digital economy, the algorithm of the matrix formula of Professor M.D. Kargopolov is recommended to consider as a matrix toolkit of production modeling, which allows visualizing and taking into account all expenses, and simultaneously determine the production expenses of products of any legal entities, including those in a cluster.

\section{References}

[1] The main activities of the Government of the Russian Federation for the period up to 2024 (approved by the Government of the Russian Federation 09/29/2018). URL: http://base.consultant.ru/

[2] On the national goals and strategic objectives of the development of the Russian Federation for the period up to 2024. Presidential Decree of 07.05.2018 N 204 (as amended on 07.19.2018). URL: http://base.consultant.ru/

[3] On the management system of the implementation of the Digital Economy of the Russian Federation program (together with the Rules for the Development, Monitoring and Control of Implementation of Action Plans for the Implementation of the Digital Economy of the Russian Federation Program). The Resolution of the Government of the Russian Federation of 28.08.2017 No. 1030 . 
[4] On the Ministry of Digital Development, Communications and Mass Media of the Russian Federation. The Resolution of the Government of the Russian Federation of 02.06.2008 No. 418 (as amended on 09/25/2018). URL: http://base.consultant.ru/

[5] On the Main Directions for Implementing the Digital Agenda of the Eurasian Economic Union until 2025. Decision of the Supreme Eurasian Economic Council of 11.10.2017 No. 12. URL: http://base.consultant.ru/

[6] Plan of measures in the direction "The formation of research competencies and technological reserves" of the program "Digital economy of the Russian Federation" (approved by the Government Commission on the use of information technologies to improve the quality of life and business conditions (protocol No. 2 of December 12, 2017)). URL: http://base.consultant.ru/

[7] GOST R ISO / IEC 19770-2-2014. National standard of the Russian Federation. Information Technology. Software asset management. Part 2. Software identification tag (approved and enforced by the Order of Rosstandart of November 19, 2014 No. 1684-st). URL: http://base.consultant.ru/

[8] About the Ministry of Industry and Trade of the Russian Federation. The Resolution of the Government of the Russian Federation of 05.06.2008 N 438 (ed. of 28.08.2018)], previously these issues were resolved at the Ministry of Construction and Housing and Communal Services of the Russian Federation (Ministry of Industry and Trade of Russia). URL: http://base.consultant.ru/

[9] On the Ministry of Construction and Housing and Communal Services of the Russian Federation. The Decree of the Government of the Russian Federation of November 18, 2013 No. 1038 (Ministry of Construction of Russia). URL: http://base.consultant.ru/

[10] On the Strategy for the development of the industry of building materials for the period up to 2020 and further perspective until 2030. The order of the Government of the Russian Federation of 10.05.2016 No. 868-p (as amended on 11.23.2016).

[11] The strategy for the development of the industry of building materials and industrial housing for the period up to 2020 (approved by the Order of the Ministry of Regional Development of the Russian Federation dated 05.30.2011 No. 262). URL: http://base.consultant.ru/

[12] On the Government Commission on Digital Development, the use of information technologies to improve the quality of life and business conditions (along with the "Regulations on the Government Commission on Digital Development, the use of information technologies to improve the quality of life and conditions of business"). The Resolution of the Government of the Russian Federation of 07.09.2018 No. 1065. URL: http://base.consultant.ru/

[13] S-A.Yu. Murtazaev, T.V. Kuladzhi, "Matrix micro-forecasting tools for the cost of innovative construction products in strategic planning," Grozny Natural Science Bulletin. Scientific and technical Journal, 2 (6), pp.62-79, 2017.

[14] T.V. Kuladzhi, A.V. Babkin, S.-A.Yu. Murtazaev, "The use of matrix tools in digital economy to assess the production of industrial products,' Digital transformation of economy and industry: problems and prospects: a monograph. Saint Peterburg: Publishing House Polytechnic. University, pp.686-727, 2017

[15] T.V. Kuladzhi, E.S. Kutukova, S.-A.Yu. Murtazaev, P.I. Vasiliev, T.S. Murtazaeva, "Matrix formula of professor M.D. Kargopolov as an instrument of internal audit accounting policies," Questions of economics and law, No 2, pp.103-114, 2016.

[16] T.V. Kuladzhi, , Kh.E. Taymaskhanov, S. A.Yu. Murtazaev, M.S Saidumov, A.Kh. Alaskhanov, "Matrix methods for determining the expenses of R \& D in a cluster," Actual problems of modern materials science, pp.58 -81, 2015.

[17] T.V. Kuladzhi, E.S. Kutukova, S.A.Yu. Murtazaev, S.A. Aliev, "Matrix formula of professor M.D. Kargopolov as a tool for calculating the expenses of innovative investment products," Problems of formation and implementation of an effective investment policy of the region: Materials of the round table. Makhachkala: ISET, DSC of RAS, pp. 33-47, 2015.

[18] T.V. Kuladzhi. Methodology for evaluating the effectiveness of design solutions in the construction complex: monograph. Arkhangelsk: SAFU Publishing House named M. Lomonosov, 2014.
[19] About the plan of measures for the implementation of the Fundamentals of the state policy of regional development of the Russian Federation for the period up to 2025. Order of the Government of the Russian Federation of 05.06.2017 No. 1166-p

[20] White Paper on Digital Platforms, Digital Registration Forms, March 20 2017 [Electronic resource] // URL: http://www.de.digital/DIGITAL/Redaktion/EN/Publikation/white paper.pdf?_blob = publicationFile \& v $=3$

[21] About information, information technology and information security. Federal law of 07.27.2006 N 149-FZ (as amended on 07.19.2018). URL: http://base.consultant.ru/

[22] On strategic planning in the Russian Federation. Federal Law of 28.06.2014 No. 172-FZ (as amended on 12/31/2017). URL: http://base.consultant.ru/

[23] On approval of the action plan for the implementation of the Strategy for the development of the building materials industry for the period up to 2020. Order of the Government of the Russian Federation of April 6, 2017 No. 630-p. URL: http://base.consultant.ru/

[24] Draft Order of the Ministry of Construction of Russia "On Approval of the Classification Method for Construction Materials, Products and Structures, and Determination of the Standard Terms of Their Operation", Russian legislation from July 16 to October 5, 2018. Consultant Plus. URL: http://base.consultant.ru/

[25] M.D. Kargopolov. Interoperable balances of expenses and results of production: theory and practice: monograph. Arkhangelsk: Publishing House ASTU, 2001.

[26] M. D. Kargopolov, "Matrix formula of production expenses and prices per unit of output (works, services)", Mathematics, economics, management: 100 years since the birth of L.V. Kantorovich. St. Petersburg: Publishing House of St. Petersburg State University, pp.146147,2012

[27] M.D. Kargopolov. Balance methods in economic calculations in an enterprise: studies. Allowance. Arkhangelsk: CPA NArFU, 2012.

[28] Leontyev V. Economic Essays. Theory, Research, Facts, and Politics. Moscow: Political Literature, 1990.

[29] V.V. Kossov. Interindustry models. Moscow: Economics, 1973.

[30] On innovative science and technology centers and on amendments to certain legislative acts of the Russian Federation. Federal Law of 29.07.2017 No. 216-FZ (as amended on 04.06.2018). URL: http://base.consultant.ru/.

[31] On industrial policy in the Russian Federation. Federal Law of 31.12.2014 No. 488-Ф3 (as amended on 27.06.2018). URL: http://base.consultant.ru/.

[32] On the coordination of activities on the use of information and communication technologies in the activities of state bodies. The ecree of the Government of the Russian Federation of 24.05.2010 No. 365 (ed. of 25.09.2018).

[33] On approval of the state program of the Russian Federation "Economic development and innovative economy". The resolution of the Government of the Russian Federation of 15.04.2014 No. 316 (as amended on 09.19.2018)].

[34] On approval of the state program of the Russian Federation "Information Society (2011-2020)". The resolution of the Government of the Russian Federation of 15.04.2014 No. 313 (as amended on 09/25/2018). URL: http://base.consultant.ru/.

[35] Compliance of English and Russian formulas in Excel (and vice versa!) + Description of formulas // http://brusentsov.com/2009/12/27/3519.. URL http://base.consultant.ru/

[36] T.V. Kuladzhi, A.V. Babkin, S.-A. Y. Murtazaev, "The prediction of the effectiveness of the production of innovative products in digital economy" Proceedings of the South-West State University. Series: Economy. Sociology. Management, vol. 7, No. 3 (24), pp. 130-147, 2017.

[37] T.V. Kuladzhi, "Matrix tools of micro-forecasting in the innovation cluster," In the collection: Monitoring and assessment of the territories of the Arctic zone: materials of IPMC: $[16+]$ Ministry of Education and Science of the Russian Federation, Arkhangelsk: KIRA, pp.21-27, 2016.

[38] T.V. Kulazhi, S.-A.Y. Murtazaev, A.T. Murtazaev, "Calculation of the expenses of structural concrete composites according to the matrix formula of Professor M.D. Kargopolov taking into account the 
technological features of production," Proc. of the Grozny State Oil Technical Univ. named M. Millionshchikov, pp. 120-130, 2013.

[39] T.V. Kuladzhi, N.V. Iskichekova, "Matrix formula as a tool for evaluating R \& D," Science of the XXI century: Problems of academic mobility of researchers and research methodology. vol. 2: Materials II MNPK. Arkhangelsk, pp.108-117, 2013.

[40] T.V. Kuladzhi, I.G. Popova, S.V. Manyshev, N.G. Fisenko, "The determination of the expenses of construction design solutions according to the matrix formula of Professor M.D. Kargopolov," In the collection: The Science of the 21st Century: Problems of Academic Mobility of Researchers and Research Methodology. vol. 2: Materials II MNPK. Arkhangelsk, pp.118-130, 2013.
[41] T. Kuladzhi, A. Babkin, S.-A. Murtazaev, "Matrix Tool for the Digital Economy," Advances in Intelligent Systems and Computing, vol. 692, pp. 1333-1346, 2018.

[42] T. Kuladzhi, I. Babkin, S.-A.Y. Murtazayev, T. Golovina, "Digital matrix micro forecast of informational and telecommunication products expenses," Proceedings of the 2017 International Conference "Quality Management, Transport and Information Security, Information Technologies", pp. 233-239.

[43] T.V. Kuladzhi, S-A.Y. Murtazaiev, Kh.E. Taimaskhanov, S.A. Aliyev, M.Sh.M. Mintsaev, 2015, ISSN (Print): 0974-6846, ISSN (Online): 09745645, www.indjst.org 